\title{
Inorganic Collections
}

\author{
Atmospheric distributions of the sensible and regimes of public space
}

\author{
Carl Douglas
}

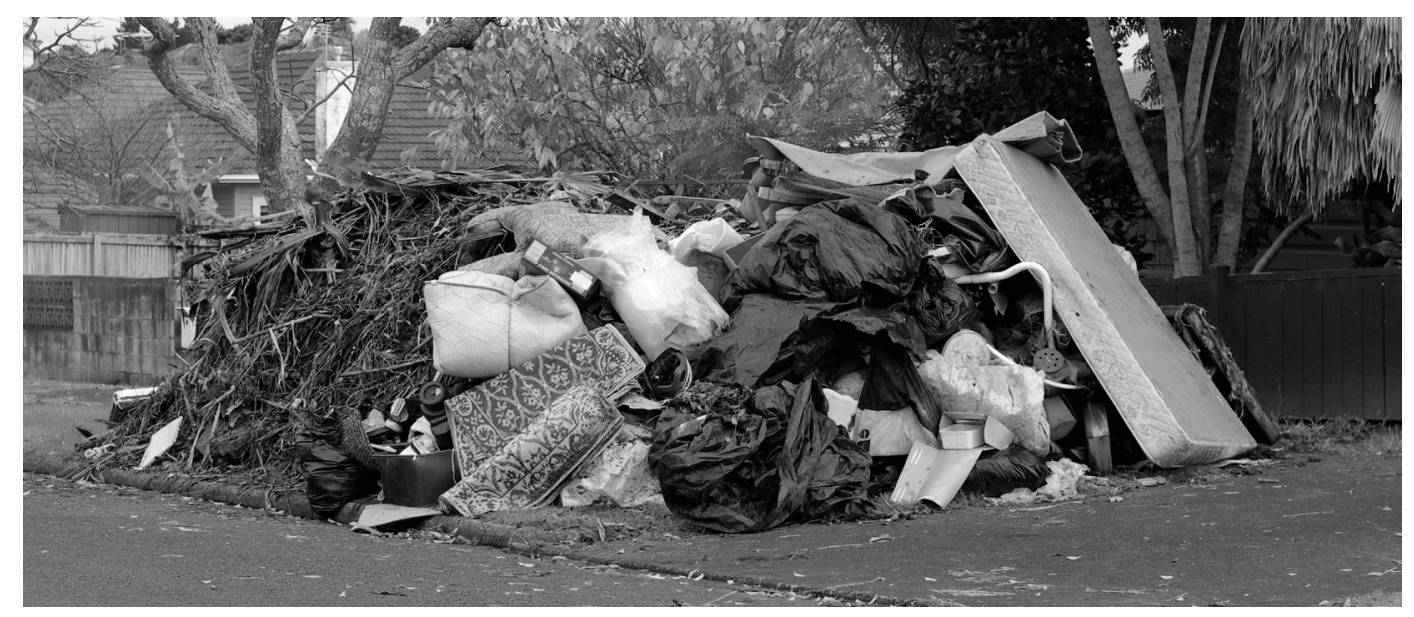

Fig. 1 Inorganic collection pile, Grotto Street, Onehunga, June 2013 [Photo: Author].

In Auckland, where I live, there is a biannual collection of household waste that can't be disposed of or recycled through the regular means. At present, the regular means is a weekly collection of landfill waste from a plastic wheelie bin, and a fortnightly collection of recyclable materials from a similar bin (our bins are 120 litres and 240 litres respectively, but this varies by suburb). Flat paper and card, glass, cans, and a number of plastics are collected into the latter and sorted at the Visy Material Recovery Facility in Onehunga. An additional bin for collecting organic food waste is scheduled to be introduced in 2015, and private companies provide services for collecting bins of garden waste (Auckland Council 2013a, 2013b; Thompson 2013).

Inorganic collections are announced for an area several days in advance, and for this brief period waste can be dumped conditionally in the street. According to the Council notification leaflet, each residence is permitted "one small trailerload" of household rubbish (Auckland Council 2014). Individual items must be liftable by two people and waste must be "placed neatly on the kerb, keeping piles clear of footpaths, driveways, fire hydrants, trees, and power and telephone poles". Collection piles cannot include anything that could reasonably be put in the weekly rubbish collection, nor any organic waste or recyclable materials. Also proscribed: building waste, tyres (in most areas), car parts, plaster board, liquids, paint, containers for gas, oil, or petrol, or hazardous waste (including solvents, car batteries, fire extinguishers, oil, broken glass). Steel items are separated out for recycling when the piles are collected, but everything else is taken directly to landfill. Collections like this don't appear to be common in other cities, where booked waste collections or drop-off systems are preferred.

In practice, however, inorganic collections are far from these ideals. Proscribed items are abundant, since residents can simply claim that someone else dumped it in their pile, and such items are usually collected anyway. Piles reach gargantuan proportions, particularly outside multi-unit dwellings. Commercial and industrial waste is illegally dumped into residential piles. Footpaths and mowing of berms are disrupted. There are legends of children closing themselves inside 
dumped fridges and suffocating when they were unable to get out. Waste dumped at unscheduled times is often ultimately collected by the Council anyway, and sometimes one assertive-looking pile is enough to convince neighbours that there must be an inorganic collection coming and trigger further piles. This overlaps with the common practice of leaving usable items at the roadside (occasionally with a sign) for free collection. Scavenging is prevalent. During an inorganic collection it is common to see vans, light trucks, or cars with trailers slowly rolling down the street examining each pile for items of interest: some scrounge scrap metal while others simply spot an item of furniture that looks salvageable. Particularly keen scavengers come from other suburbs and work systematically along the piles. Some scavenged items are destined to be re-dumped into another inorganic collection pile, either immediately or later on. Something of the air of a neighbourhood garage sale is discernable (Bridgeman 2013).

As of July 1, 2015 inorganic collections will cease, to be replaced by "community recycling hubs" and booked waste collections (Theunissen 2014). The reasons given are that too much recyclable material was being thrown out, and that the collection piles were messy and dangerous. As what will soon be part of the history of Auckland's urban culture, inorganic collections are also a significant moment for discerning the configuration of its public space. In what follows I will employ inorganic collections as a probe for mapping the regime of public space at work in Auckland's suburban streets.

\section{The administratively rationalised city}

When Baron von Haussmann implemented his Second Empire urban plan for Paris (1853-1867), he inaugurated a new model for cities. Through the dense urban fabric of streets and alleys, he cut broad boulevards:

In a space some thirty meters wide and up to two kilometers long, Haussmann concentrated the services and the circulation of the new commercial city. Paved with new macadam, lit with the latest design of gas light, carefully planned to separate pedestrian, stroller, loiterer, ambling service vehicle, and rushing carriage, planted with rows of trees to ensure shade in summer, provided with underground piping for rain water, sewerage, and gas, cleaned with the aid of scientifically designed gutters, faced by the uniform height of the residences and stores of the nouveau bourgeoisie, and carefully sited to point toward a monument or vista as the object of civic pride or aesthetic pleasure, the boulevard of Haussmann was in effect the epitome and the condenser of Second Empire daily life: the modern artifact par excellence. (Vidler 1978: 94-5)

Walter Benjamin quipped that these new streets were necessitated by the blossoming size of womens' skirts, and in a more serious tone proposed that the "true goal of Haussmann's projects was to secure the city against civil war" (1999: 133, 12; Douglas 2007). While the boulevards certainly served immediate political ends, however, they need also to be understood more broadly as articulating a new ideal, the city's administrative rationalisation:

Haussmann's treatment of Paris was in fact the first total conceptualization of what we understand by "the modern city". It heralded a technocratically minded, comprehensive approach to town planning in which a rationalised circulatory network would once and for all sweep away ... the dross of the community's promiscuous life through time ... The city as a sleek, efficient machine was his unacknowledged legacy to the modern movement. (Kostof 1994: 11) 
The city was treated as a single integrated entity, in keeping with an emerging "techno-cosmopolitanism ... an understanding that society must be constructed, planned, and organized through art and science ... the operationalization of history, society, and culture" (Rabinow 1996: 59). Central to this operationalisation were the metaphors of organism and machine (Graham \& Marvin 2001: 62). Although the organic and machinic might superficially appear to be opposing models, they were in fact united by an "implicit theory of assemblage" (Douglas 2009: 97) in which parts are only valorised with respect to a greater whole. De Landa (following Deleuze), offers the term "relations of interiority" to describe this kind of relation: "component parts are constituted by the very relations they have to other parts in the whole. A part detached from such a whole ceases to be what it is, since being this particular part is one of its constitutive properties." (De Landa 2006: 9) ${ }^{1}$ According to the integrated model, any element that isn't serving the whole - anything disruptive, broken, or divergent - isn't part of the city at all. ${ }^{2}$

Understandably, this model of the city as a "sleek, efficient machine" had clear consequences for public space: what it was understood to be, how it was formed, and the ways in which it counted as public. Graham and Marvin point to Haussmann's Parisian works as a transitional point in the conception of the street as a public space. Previously streets had been primarily civic spaces where public relations could take place in person: "the primary ingredient of urban existence ... a structure on which to weave the complex interactions of the architectural fabric and human organization ... meeting spaces between more or less privileged citizens” (Çelik 1994: 1). Under the unified city regime, however, streets became conduits for bundled technical systems; a rationalised circulatory system.

This regime dominated (and arguably originated) the discipline of modern city-planning, and the persistence of its effects in contemporary cities - even antipodean ones of the 21st century - can be observed in the spatial order of the streets. Although technologies of transit have evolved into new forms, new infrastructures of electricity and telecommunication have arisen, and agencies of city formation have multiplied, street-as-infrastructure has remained consistent. In the Auckland Council's 2008 document Auckland Liveable Arterials Plan, the operation of "arterial" streets is enumerated in terms with which Haussmann would be entirely comfortable: sections discuss travel lanes, cyclists, pedestrians intersections, bus lanes, parking, "access management" (6), road safety, etc. In the section on pedestrians we find that pedestrianisation "adds to the vibrancy and quality of the public realm, through enabling face to face contact and interaction" and that a minimum footpath standard will be applied "to enable basic non-vehicular movement to and between properties" (2). While pedestrians might contribute a measure of "vibrancy", what is fundamentally allowed for is only a "basic non-vehicular movement". Emphasis is heavily on circulation, and on the street as servicing the private realm.

The streets of Haussmann's Paris were spaces for the performance of bourgeois identity, commerce, aesthetics, and person-to-person interaction; allied to a sustaining technical infrastructure concealed below, behind, and beyond. Benjamin observes this acutely, describing the patrons of the boulevards ("phantasmagoria ... rendered in stone"; 1999: 24) as audiences for spectacle and commerce, pointing to them as newly-minted subjects of bourgeois capitalism, while simultaneously noting how sewers and concealed technical networks operate to provision this phantasmagoric space and extract anything that might tend to disrupt it.

In the Haussmannian model of public space, the public good is the wellbeing of the administratively-imagined city, and the city's inhabitants are either an audience for urban spectacle or simply one of the flows to be kept in smooth circulation. This vision of public space is also visible in the Auckland Liveable Arterials Plan: "Pedestrianisation adds to the vibrancy and quality of the public realm, through enabling face to face contact and interaction." This anodyne phrase receives no unpacking, and the document immediately segues into measures "to maximise pedestrian 
movement" (2). The suburban street is drained of all operation other than smooth circulation and a vague aesthetic aspiration for "vibrancy". These factors are treated as intangibles, a gloss coat over what is fundamentally an infrastructural system. In the 2013 Auckland Plan, we find a diagram of the "priority areas" that will lead to Auckland becoming "The World's Most Livable City" (2013: 166). Alongside water, energy, transport and data infrastructure is listed "social" infrastructure, in which is included education, health and justice. That these aspects of life could be envisaged as being just one more class of infrastructure is characteristic of the administrative rationalisation of the city. The splitting of public space into atmosphere and infrastructure presages their separation into concentrated sites of spectacle and commerce, and the conduits by which they are serviced.

Jacques Rancière identifies the production of the street as a space of circulation with the policing of public identity:

"Move along! There is nothing to see here!” The police says that there is nothing to see on a road, that there is nothing to do but move along. It asserts that the space of circulating is nothing other than the space of circulation. Politics, in contrast, consists in transforming the space of 'moving-along' into a space for the appearance of a subject: i.e. the people, the workers, the citizens: it consists in refiguring the space, of what there is to do there, what is to be seen or named therein. (2001)

In Rancière's picture, the police here need not be actual uniformed officers instructing people to keep moving. For him, "police" names a regime in which everything is everything is assigned its place, and nothing can be recognised apart from the place it occupies (2004: 89). The infrastructuring of the city as an aspect of its administrative rationalisation aims at precisely this kind of allocation: the production of spaces where there is something to see, through the simultaneous production and suppression of spaces where there is nothing to see, and all that remains is to keep moving.

\section{Atmospheres}

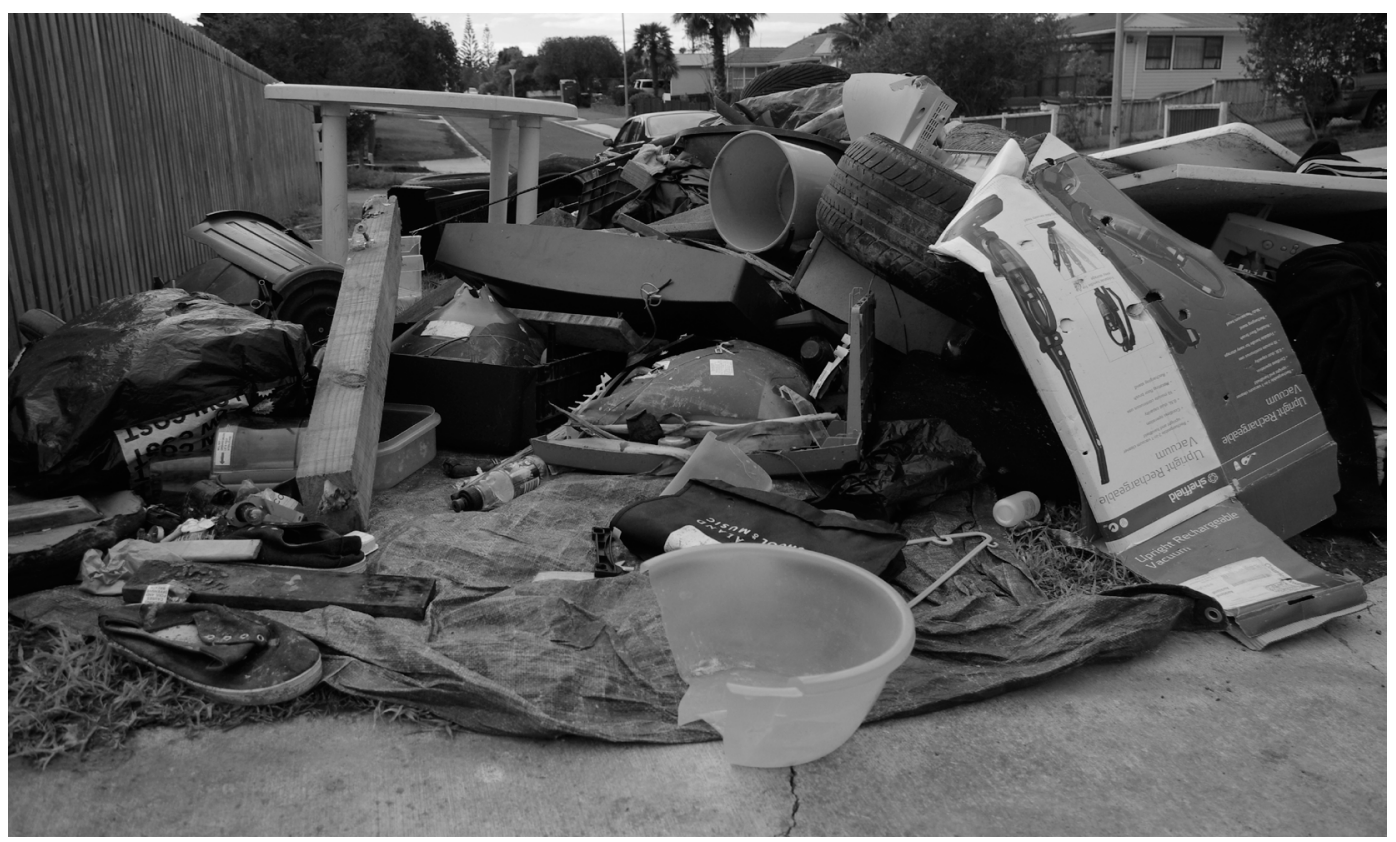

Fig. 2 Inorganic collection pile, Cambourne Road, Papatoetoe, July 2013 [Photo: Author]. 
In the administrative city, the production of atmosphere as phantasmagoria or spectacle is essential as part of the policing of a regime in which everything has its place and its proper conduits. But in taking cognisance of the relation of atmosphere to technical systems, we can gain insight into opportunities for intervention and interruption of this regime in the manner Rancière describes.

Gernot Böhme (1993) claims that atmosphere is an under-rated concept, usually relegated to being a vague or amateurish expression of aesthetic experience. To the contrary, he insists that it is fundamental, not only to a class of experience called "aesthetic", but to the formation of subjects. The affects an atmosphere has on a subject aren't limited to excitations of existing perceptual circuitry, but include the very configuration of a subject itself. Spinoza writes of "affections of the body by which the body's power of acting is increased or diminished, aided or restrained" (1994: 140), and in this sense, Böhme's atmospheres are affective: affects don't simply take place on a body the capacities and sensitivities of which are already established; rather in them, bodies are capacitated and sensitised.

In Peter Sloterdijk's thinking of atmosphere this capacitation and sensitisation is expressed as life-support: subjects are not only formed, but maintained in existence atmospherically. Atmosphere, he points out, is not only experienced, but breathed. Wherever we are, claims Sloterdijk, we're on life-support of some kind, "air-condition systems in which construction and calibration ... it is out of the question not to participate” (46). Both Böhme and Sloterdijk point us to attend to how spaces produce and sustain not only certain experiential effects, but the subjects which are found within them. Atmosphere is more than an aesthetic, perceptual, ambient condition; it is to do with the technics of subjectivity. What subjects are capable of doing and perceiving is formulated atmospherically.

In his recent work Invasive technification (2012) Böhme offers the concept of "technostructures", the network of relationships that allow individual technological things to perform:

... it becomes clear that many technical devices that appear designed for use in isolation also only perform their intended functions when they are connected to a network, or when used in the context of a broader structure: a car, for example, is really only serviceable as a car along with a network of streets and roads, a network of service stations, an insurance system, a system of laws, etc. Outside of this entire web of relations - the whole technostructure-a car comes to grief about as quickly as a fish out of water. (31)

Atmospheres could be seen as technostructures for subjects (although this isn't something Böhme himself suggests): a web of relations along which affects are transmitted, and without which they too are "fish out of water". ${ }^{3}$ The bourgeois subjects of Haussmann's Paris can only exist when they are connected to the network of arcades, panoramas, gaslit interiors, works of art, governing bodies, capital, factories, cameras, sewers, etc. This network forms the atmosphere in which these subjects are able to breathe, the relational space necessary for them to perform. This is explicit for Sloterdijk, whose model of atmosphere centres on sustenance rather than perception. For him it's not only "individual technological things" (Böhme 2012: 31) that rely on an infrastructure, it's also human subjects. Sloterdijk insists on the possibility of an "atmotechnics" (2009: 23), that atmospheres be understood as designed, assembled, structured, not only accounted for as experience. ${ }^{4}$

In Rancière's description of public space, what is visible, sayable, and able to be done is not natural or absolute, but must be policed. Perceiving, speaking, and acting subjects result from a particular regime, a "distribution of the sensible" (2004: 85), a network of relations in which each member is intricately sensitised and enabled to speak and act. This regime rarely appears personified as a police officer instructing us to move along and denying that there is anything to see; far more 
frequently it makes itself felt in the apparently "self-evident facts of perception" (85). What else is a street for but moving along?

Böhme points out the way we use atmosphere as a term for something difficult to pin down, "indeterminate" something that causes us to fall into "speechlessness" or "embarrassment" (1993: 113). We are indisputably affected, but unable to specify exactly how or why. Rancière and Sloterdijk indicate that this experience results from a distribution of the sensible or an atmotechnics. The administrative rationalisation of the city is precisely this kind of distribution or atmotechnics: it sustains subjects for whom certain facts are self-evident, for whom certain things are spectacularly visible and others are not to be seen, and for whom certain relations are normalised and others exceptionalised. The apparent obviousness of the Auckland Liveable Arterials document's statements about streets points to a successful air-conditioning operation.

\section{Exceptional and articulate matter}

The handling of waste is symptomatic of this atmotechnics. The city-machine ideal is for waste to be seamlessly and invisibly whisked away. Since Haussmann put the sewers underground, channeling waste out of the boulevards and into a concealed system of containment and handling, waste has articulated a boundary condition of public space; a horizon separating the visible and invisible.

When I deposit my waste into a rubbish bin, I imagine that it passes an event horizon and ceases to exist. In the corner of my kitchen, beside my desk, against the wall of my office, and set in concrete on the pavement outside, are gaping holes that notionally lead out of sight and relation. In propelling something through this opening, I absolve myself of responsibility for its future career, congratulate myself for civic-mindedness, and imagine myself free from having anything to do with it. Early one morning a robot arm will empty the sealed plastic receptacles I've placed on the kerb (unless the containment of the bin fails due to the enthusiasm of a neighbour's dog), and my waste has gone away.

"Away" is of course a very short list of specific places: in Auckland, various transfer stations and then one of four active landfill sites (Auckland Council 2013b). Timothy Morton writes that implicit in the concept of throwing things away is the concept of an infinite exteriority; and further contends that the modern concept of nature itself is little more than the idea of an away formed as a necessary counterpoint to capitalist modes of production:

When we flush the toilet, we imagine that the U-bend takes the waste away into some ontologically alien realm. Ecology is now beginning to tell us of something very different: a flattened world without ontological U-bends. A world in which there is no "away". (2012)

Nature was always "over yonder", alien and alienated. Just like a reflection, we can never actually reach it and touch it and belong to it. Nature was an ideal image, a self-contained form suspended afar, shimmering and naked behind glass like an expensive painting. In the idea of pristine wilderness, we can make out the mirror image of private property: Keep off the Grass, Do Not Touch, Not for Sale. Nature was a special kind of private property, without an owner, exhibited in a specially constructed art gallery. (2010: 5-6)

This imagined exterior is actually a place carefully constructed and maintained as a counter-space to the 'here' of the city. The "waste regime" (Gregson \& Crang 2010) of the administratively rationalised city is founded on producing and maintaining here and there, home and away. Away is a 
public space: public in the sense of being shared and of communal concern, but also public in the sense that it forms "an environment of strangerhood" (Warner 2002: 75), articulating our relationship with strangers. Haussmann's boulevards are underpinned by invisible sewers draining away uncomfortable, inconvenient, ugly, unhealthy, obsolete and obstructive matter, so that the boulevards can become places of spectacle. These systems have expanded until, in Auckland's present, they have consumed the streets themselves in an all-encompassing system of circulation.

The public space of the administratively rationalised city relies on the careful construction and laborious physical and symbolic maintenance of an interior and an exterior; a finite 'here' of desirable or useful things moving in orderly synchronicity, and an infinite 'away' which absorbs and isolates us from the undesirable or redundant which cannot be made to move in sync. Waste passes across the horizon between these two spaces, through a porous and sometimes leaky membrane that purports to selectively permit and prevent affects from passing between here and away. ${ }^{5}$

In this "waste regime" (Gille 2010: 1049), a public atmosphere is supported by conduits channelling "waste streams". A waste stream is waste conceived of as inarticulate and generic, relatively homogenous, a substance to be managed, "translated into metrics - tonnes and targets" (Gregson \& Crang 2010: 1026). Once it passes the event-horizon of the bin, it's not the top of the celery, a dried paint roller or a Hairy Maclary nappy: it is 'waste', a generic substance for specialist handling. Specific properties and potentials are elided. The celery isn't food, the paint isn't poison, the dog isn't cute; there is just waste, inconvenient and potentially dangerous or unhealthy. Inorganic collections are comprised of things that don't pass seamlessly or invisibly; that cannot be whisked and that don't fit down the regular conduits. It is a lump that sticks in the craw of the administratively rationalised city: exceptional matter, in the sense that its resists assimilation into generic waste and that exceptions to the regular order of the street are made for it.

Manuel Castells characterised the "space of flows" as the dominant spatial logic of the contemporary urbanised world (1996: 407), but the handling of inorganic waste might give us reason to qualify his account. Things can indeed be made to flow, but only so long as conduits are available, and the things in question can be formatted correctly. Flow is not a fundamental condition, but something produced. Inorganic collection waste remains articulate and exceptional, in the face of a regime that attempts to make it a homogenous waste stream as part of forming a public atmosphere. A distribution of the sensible makes certain things discernable and others undetectable. Atmosphere is not solely a matter of what is perceived, but of what is perceptible. The networks of conduits through which things are made to circulate in the administratively rational city are a means by which a 'here' and an 'away' are produced. In the conduits themselves, the specificities of discarded items are made invisible by being rendered down into a waste stream; their myriad capacities overwhelmed by the capacity to cause offense. What is made imperceptible by the circulating flows of the administrative waste regime is the haeccity of things "as vivid entities not entirely reducible to the contexts in which (human) subjects set them” (Bennett 2010: 5). In the term applied by Jane Bennett, inorganic collection waste is matter that resists being stripped of this "vibrancy" (2010: xiii).

\section{Public relations}

From within this regime, I make unilateral decisions about waste. From within my private space I decide that some item is of no further value, and bin it. With the results sealed in an opaque receptacle, the process of my evaluation is inscrutable. I can unilaterally decide that something should be buried, burned, or pumped out to sea. Waste is constituent of a private relation between myself and the city, infrastructurally mediated. By being removed from the interpersonal domain, siphoned away from public space, waste is no longer permitted to perform in the relation between me and my neighbour. 
When I put out waste for the inorganic collection, however, these evaluations are made public, staged in sight of my neighbours and passers-by. This is what drives the practice of scavenging. What to me is a box of old magazines may be a trove of classic 1990s' Vogues to someone else; the furniture I deem irreperable may simply require someone with a little more motivation or practical skill to restore; the defunct analog television has a few dollars worth of copper windings inside; and while pole-tennis may have given way to another recreational pursuit for me, it may excite my neighbour's kids. In this respect, the inorganic collection undermines or overflows the waste regime of the administratively rational city.

The air-conditioning systems being observed sustain subjects for whom waste is a strictly private matter, and who relate to one another only via the city's technical interface. Böhme, in his recent work on "technification" writes:

... our society has acquired an all-pervasive technological infrastructure, which has become one of the major forces that shape the very possibilities and meanings of social life. The introduction of new forms of technology is thus part of the overall process of social reproduction, and brings with it inevitable changes to the very structure of our society. (2012: 119)

Böhme warns that "technostructures are taking over the function of social integration", and he adduces "our society's enormous networks of supply and waste disposal” (34). Böhme refers to a single generalised technological infrastructure, but if we consider the proliferation of specific technological infrastructures like that of waste disposal, his statement is apt. The "very possibilities and meanings of social life" - what it means to be social, for there to be a public domain, what forms coexistence can take and the significance of those forms - are structured, filtered, and conditioned technically. In his theory of technostructures the capacitation and sensitisation first met in his account of atmosphere as a structure of perception take on a more sinister tone. The interfaces and conduits and handling sites of the waste management network interpose between people such that a dimension of public experience is elided. Gregson, Metcalfe and Crewe argue for the importance of recognising "practices of divestment" (2007: 187) as a constituent of our social identities. Handing down, donating to charity, re-selling online or at a garage sale, gifting, dumping, storing, lending, burning, recycling, and discarding " $n o t$ only work to move objects along, but work back, as practices, on their divestors ... to constitute narratives of us, of others and our relations to them" (198). ${ }^{6}$ Public relations are produced through practices of divestment, and the upcoming cessation of inorganic collections in Auckland reinforces the relation between private individuals and the city by narrowing the range of these practices and re-siting them.

The Auckland Waste Management and Minimisation Plan (Auckland Council 2013b) lists numerous "negative impacts" of the current inorganic collection system: "health and safety issues for collectors and the public, mess, security issues, damage to reusable items through scavenging, illegal dumping and providing a disincentive to product stewardship" but counters this only by acknowledging that "they are popular with some parts of the community" (49) without any attempt to account for this popularity. To replace the kerbside collection of inorganic waste, "community recycling hubs" are proposed. The new privately-run hubs will offer "job and training opportunities", and according to the Council's solid waste manager Ian Stupple, might be "almost a community facility like a leisure centre or a library where people would hopefully be attracted to go to on a regular basis" (Theunissen 2014). While these hubs may offer considerable benefits, they also need to be seen as part of an ongoing project to assign everything in the city its proper place; and as part of the ongoing conversion of streets into conduits. The range of permissable activities that can be carried out in the street becomes progressively narrower until the street is no more than a bundled technical system under a thin landscape veneer; a space in which it is only possible to move along because there is nothing to see. 


\section{Summary}

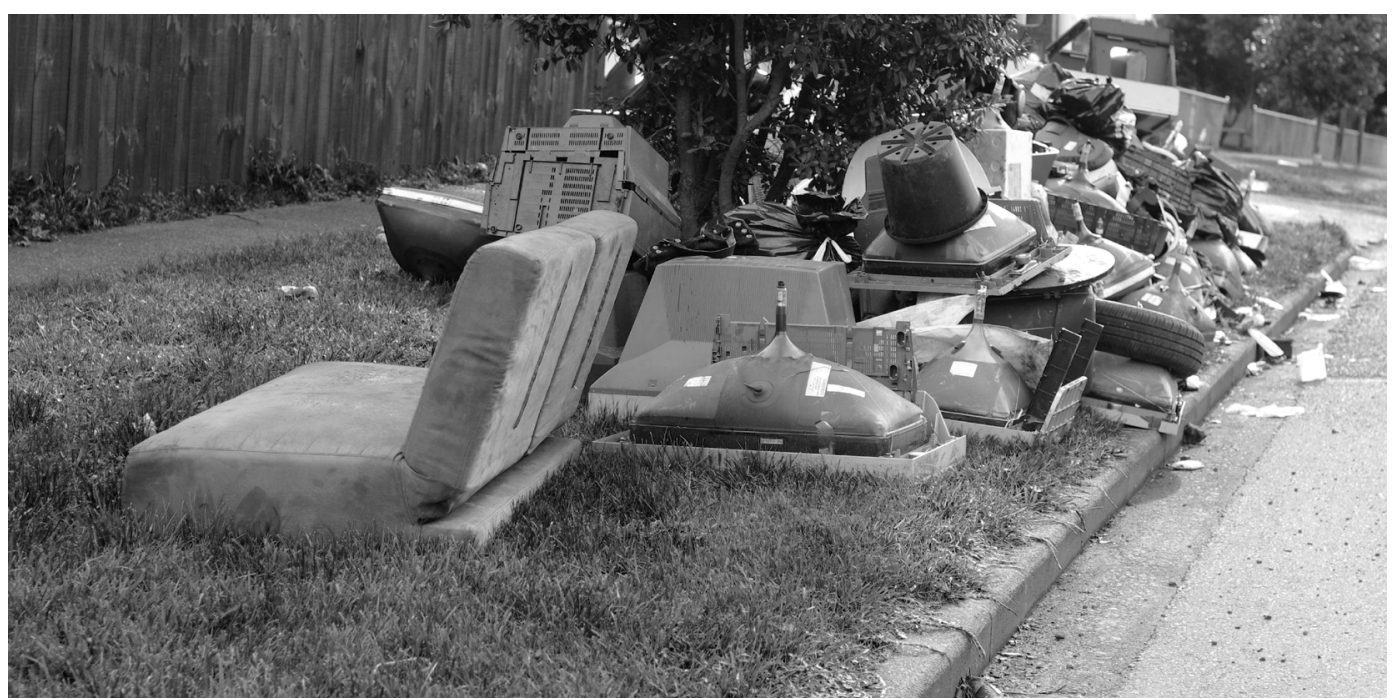

Fig. 3 Inorganic collection pile, Felix Street, Onehunga, June 2013 [Photo: Author].

It has been my premise here that public space, and what the term "public" means, is neither universal nor fixed but on the contrary is assembled and maintained, and can be contested. The regime of public space to which I have referred here as the administratively rationalised city, and exemplified in Haussmann's Paris, is a "police” regime. Accordingly, everything is to be assigned its proper place and operation, without remainder: "The essence of the police is to be a partition of the sensible characterized by the absence of a void or a supplement ... In this fittingness of functions, places, and ways of being, there is no place for a void" (Rancière 2001). But this isn't simply a matter of the smooth operation of a city's hardware: it incorporates the allocation of roles for the occupants of the city themselves. Nor is this simply the organising or coordinating of pre-existing subjects. Rather, this distribution is how sensitive and capable subjects are produced.

In this way, I have linked Rancière's distribution of the sensible with the concept of atmosphere as developed by Böhme and Sloterdijk. Atmospheres are co-presences structured affectively such that subjects are sensitised and capacitated. If atmosphere is "the common reality of the perceiver and the perceived" (Böhme 1993: 122), this is because in it, certain things are made seeable, sayable, and operative, while others are rendered imperceptible, mute and ineffective. For a shared atmosphere to be robust and enduring, much work is needed to sustain it. The work that goes into this sustenance is perhaps best discerned at the edges, at the horizon beyond which this work is habitually concealed, and at moments of rupture or breakdowns in air-conditioning (Douglas 2011). This is where something as apparently banal as local quirks of waste collection takes on atmo-technical significance.

The Auckland Liveable Arterials document and The Auckland Plan exhibit an impoverished concept of streets dominated by smooth circulation. Waste is problematic for circulation because it tends to clog and slow it; and inorganic collections are comprised of things that resist being assimilated into a waste stream to be whisked away. In the handling of such resistant matter, we gain insight into how the administratively rationalised city (as an active ideal, far from an historical model) seeks to assign places, and to suppress anything that can't be assigned. 
On these grounds, I consider inorganic collections as more than a curiosity of Auckland's urban culture. Momentarily, when the inorganic collection takes place, the policed order of the street is disrupted. For a short time, waste is not a private matter handled invisibly between myself and the city; but something that activates relationships (disputes, perhaps, but also potentially exchanges or discoveries of things in common or intriguing differences) with my neighbours. 'Away' is temporarily close by, and the fiction of the infinite exterior wobbles on its footing. 


\section{References}

Auckland City Council (2008). Auckland liveable arterials plan. Auckland, NZ: Auckland City Council.

Auckland Council (2013a). Get your rubbish sorted - 2013. Your guide to rubbish and recycling in Auckland. Retrieved from http://www.aucklandcouncil.govt.nz/EN/environmentwaste/rubbishrecycling/Documents/ rubbishrecyclingguide2013.pdf

Auckland Council (2013b). Auckland waste management and minimisation plan. Retrieved from http://wasteplan. aucklandcouncil.govt.nz

Auckland Council (2013). The Auckland Plan. Retrieved from http://theplan.theaucklandplan.govt.nz Auckland Council (2014). Inorganic Collections. Retrieved from http://www.aucklandcouncil.govt.nz/EN/ environmentwaste/rubbishrecycling/Pages/inorganiccollections.aspx

Benjamin, W. (1999). The Arcades Project. Cambridge, MA: Harvard University Press.

Bridgeman, S. (2013, Mar 14). Traumatised by inorganic collections. The New Zealand Herald. Retrieved from http:// www.nzherald.co.nz

Bennett, J. (2010). Vibrant matter. A political ecology of things. Durham, NC: Duke University Press.

Böhme, G. (1993). Atmosphere as the fundamental concept of a new aesthetics (Trans. D. Roberts). Thesis Eleven, 36, pp. 113-126.

Böhme, G. (2012). Invasive technification. Critical essays in the philosophy of technology. London, UK: Bloomsbury. Castells, M. (1996). The rise of the network society. Oxford: Blackwell.

Çelik, C., D. Favro and R. Ingersoll, Eds. (1994). Streets. Critical perspectives on public space. Berkeley, CA: University of California Press.

De Landa, M. (2006). A new philosophy of society. Assemblage theory and social complexity. London, UK: Continuum.

Douglas, C. (2007). Barricades and boulevards. Material transformations of Paris, 1795-1871. Interstices, 8: 31-42. Douglas, C. (2009). Contract, crowd, corpus and plasma. Architectural and social assemblages. Interstices, (10): 97-108.

Douglas, C. (2011). Off the grid. Infrastructure and transformational space. Access, 30.

Douglas, M. (2002). Purity and danger. An analysis of concept of pollution and taboo. London, UK: Routledge. Kostof, S. (1994). His majesty the pick. The aesthetics of demolition. In C. Çelik, D. Favro and R. Ingersoll (Eds.), Streets. Critical perspectives on public space, pp. 9-22. Berkeley, CA: University of California Press.

Gille, Z. (2010). Actor networks, modes of production, and waste regimes: reassembling the macro-social. Environment and Planning A, 42: 1049-1064.

Graham, S. and Marvin, S. (2001). Splintering urbanism. Networked infrastructures, technological mobilities and the urban condition. London, UK: Routledge.

Gregson, N. and Crang, M. (2010). Guest editorial. Materiality and waste. Inorganic vitality in a networked world. Environment and Planning A, 42:1026-1032.

Gregson, N., Metcalfe, A., and Crewe, L. (2007). Moving things along: the conduits and practices of divestment in consumption. Transactions of the Institute of British Geographers, 32: 187- 200.

Latour, B. (2009). Spheres and networks. Two ways to reinterpret globalization. Harvard Design Magazine, 30 (Spring/Summer), 138-144.

Morton, T. (2010). The ecological thought. Cambridge, MA: Harvard University Press.

Morton, T. (2012). Peak nature. Adbusters, (98). Retrieved from http://www.adbusters.org/magazine/98/peak-nature. html

Rabinow, P. (1996). Essays on the anthropology of reason. Princeton, NJ: Princeton University Press.

Rancière, J. (2001). Ten theses on politics. Theory and Event, 5(3). Retrieved from http://muse.jhu.edu/journals/ theory_and_event/

Rancière, J. (2004). The politics of aesthetics. London, England: Continuum.

Sloterdijk, P. (2009). Terror from the air. Los Angeles, CA: Semiotext(e).

Sloterdijk, P. (2011). Spheres. Volume I. Bubbles. Microspherology. Los Angeles, CA: Semiotext(e).

Spinoza, B. de (1994). A Spinoza reader. The Ethics and other works (Trans. E. Curley). Princeton, NJ: Princeton University Press.

Thompson, W. (2013, Oct. 15). Revamp for Auckland's rubbish rules. The New Zealand Herald. Retrieved from http:// www.nzherald.co.nz

Theunissen, M. (2014, Mar 30). Inorganic pick up scrapped. The New Zealand Herald. Retrieved from http://nzherald. co.nz

Vidler, A. (1978). The scenes of the street. Transformations in ideal and reality, 1750-1871. In S. Anderson (Ed.), On Streets, pp. 28-111. Cambridge, MA: MIT Press.

Warner, M. (2002). Publics and counterpublics. New York, NY: Zone Books. 


\section{Endnotes}

1. De Landa articulates this distinction in the context reading Deleuze's concept of "assemblage" (De Landa 2009; Deleuze \& Parnet 2007). De Landa's account of assemblages is arguably more analytical than Deleuze's (Deleuze \& Parnet 2007) or Deleuze and Guattari's (1987). De Landa makes the distinction between relations of interiority and relations of exteriority the constitutive distinction of assemblages: "the main theoretical alternative to organic totalities is ... assemblages, wholes characterized by relations of exteriority" (2009: 10). My use of the concept of assemblage is limited to this distinction; a thoroughly Deleuzo-Guattarian application of the concept of assemblage (or even a consistently De Landian one) is outside its scope.

2. The model of the city as machine or organism may appear to have been superceded by the models of network or ecology. Graham and Marvin argue that the "integrated ideal" is in the process of collapsing into a new "splintered urbanism" (2001), pointing to increased privatization and uneven distribution of infratructure and servies. The concept of a unified city, however, remains thoroughly cemented in the administrative forms of the city. Networks and ecologies often serve as new images of technical or natural unity, and it is for this reason this paper prefers Rancière's idea of the political as something that resists any form of totalisation.

3. This is not a link Böhme expicitly makes, to my knowledge. It may however be nascent in his discussion of the "stage-management" of commodity aesthetics (this volume: $p$. <Bianca, plse insert page number here when pages are stable>). Atmospheres may affirm subjects and intersubjectivity, but may equally, like technostructures, enframe and entangle them in technological mediations.

4. Sloterdijk is no technological determinist, however: subject formation doesn't simply result from technical things. On the contrary, one of the most important aspects of atmosphere to which he points is its "symbolic air-conditioning", a production of meaningful space that he situates as a primal human activity. (2011:46)

5. As Bruno Latour puts it: "No outside is left. As usual Peter [Sloterdijk] has a striking way to bring this up when he says that the earth is finally round: Of course we knew that before, and yet the earth's rotundity was still theoretical, geographical, at best aesthetic. Today it takes a new meaning because the consequences of our actions travel around the blue planet and come back to haunt us: It is not only Magellan's ship that is back but also our refuse, our toxic wastes and toxic loans, after several turns." (2009:144)

6. Mary Douglas' famous proposition that dirt "is the by-product of a systematic ordering and classification of matter" (2002:44) is questioned by Gregson, Metcalfe and Crewe because she seems to indicate that social order is founded on the exclusion of unwanted matter itself rather than various practices in which exclusion occurs. 